\title{
Managing Nigerian Universities for Better Students' Participation in Voluntary Community Services
}

\author{
Chika Josephine Ifedili \& Maurine Egenti \\ Faculty of Education, University of Benin \\ P.O. Box 10073, Ugbowo, Benin City, Nigeria \\ E-mail: theifedilis@yahoo.com
}

Received: December 26, 2011

Accepted: January 27, 2012 Published: March 1, 2012

doi:10.5539/res.v4n1p230

URL: http://dx.doi.org/10.5539/res.v4n1p230

\begin{abstract}
The study investigated the organization and management of voluntary communities services in Nigerian universities following the attitudes of insensitivity among staff, students and graduates of various universities' communities. The population of the study was all 27 federal Nigerian universities. A random sample of 6 federal Nigerian universities $(22.22 \%)$ was used for the study. From each university, a stratified random sampling method was used to select 100 male and 100 female students and 50 male and 50 female staff to participate in the study. A total of 600 male and 600 female students and 300 male and 300 female staff participated in the study. The instrument used in gathering the data was the questionnaire designed by the researcher titled Management of Community Service Inventory (MCSI). The questionnaire was made up of two parts: Part A was based on respondents' personal data while Part B contained 15 questions bothering on planning and organization of community services, willingness of both staff and students to render voluntary community services, barriers to effective voluntary community servicing, management 's efforts to promote voluntary community services etc. The validity of the instrument was done by both experts in educational administration and educational psychology. Test-retest method was used to ascertain the reliability of the instrument. A Z-Test and common percent were the statistics used to analyze the data. The major finding was that there was poor organization and management of community services and students were very willing to participate. Based on the findings, the major recommendation was that various universities' management should endeavor to make voluntary services operative.
\end{abstract}

Keywords: Managing, Universities, Nigeria, Students, Participation, Voluntary, Community, Services

\section{Introduction}

Education is all about acquisition of knowledge, skill and right attitude and values. The attitudes and values of students constitute not only an important integral dimension of their education, but also the critical factor in the level of discipline that one should expect in the school system, and indeed the larger society. According to Akerele (2000), the four things required to take the black people to the promised land are responsibility, awareness, power and unity. Community service which is the new method of learning and student development, is an important aspect of education which Nigerian educationists have not been able to properly create public awareness on its importance. This is one of the reasons why there are so many unexpected outcomes in our present education delivery. Corruption, no respect for fellow human being, tribalism etc are just but a few of these unexpected outcomes of education. Aghenta in 2001, speaking on the dysfunction of education in Nigeria, opined that education is supposed to instill discipline and engender honesty, hard work and morality. However indiscipline and dishonest practices have become the order of the day. Education has not liberated the educated Nigerians from the bondages of parochialism, ethnicism, tribalism, oppression, injustice etc. Education has not affected attitude to work, to neighbors and to others. It must be noted that the universities have three judicial functions to perform which are teaching, researching and community services. However, how well the community services' functions are performed need to be investigated. It is not enough to give light and water which are often epileptic in their supply to the community and forget about them. As long as the university is located at a given community, there is need to continuously help the community in various ways. 
A community service can be seen as a voluntary performance of an action by someone that will benefit his or her community. Getting involved in one's community makes it livelier and healthier. One volunteers oneself in order to provide services and help. Some examples of community services in Nigerian universities can be voluntary tutoring of the less privileged, voluntary helping in security of the campus, baby sitting, organizing sports for the youths, organizing free activities that will bring happiness to the community, filling potholes, bringing light and joy where there is darkness and sorrows, environmental sanitation etc. In short it is a situation where one is trying to make a world a better place for all. Community service has so many benefits which are psychological, social, cognitive critical thinking and problem solving skills, political and civic awareness etc In fact, in developed countries like United States of America, credits or scholarships are given to students who embark on special and highly recognized community services. The gesture is to motivate other students.

In a study carried out by Boss (1994) on community service at University of Rhodes Island on 71 undergraduates, she found that community service work combined with discussion of relevant moral issues is an effective way of moving students into the post conventional stage of principled moral reasoning. She also observed that that affected students positively in the areas of leadership, social maturation, autonomy and personal competence, awareness of interest value aspirations, religious views and decrease in irrational prejudices.

At the Indiana University of Bloomington, Kuh (1995) discovered in his study that out of class experience associated with learning and personal development resulted in critical thinking, rational and organization skill to life outside the classroom and leadership responsibility.

In another study carried out by Serow and Dryden (1990), spiritual and religious values affected community services while emphasis on professional success showed negative relation. Bungle, Phillip, and Hudson (2004) in their study found that the service learning was a sine qua non to right attitude.

There is high need to deliver right education which will bring about right attitude in the citizenry. One's environment affects the individual's behavior. If good motivation is put in place, people will perform better. An attitude can be said to be a predisposition to evaluate an object to a favorable or unfavorable manner. Attitude involves both feelings and beliefs. Once attitude is formed, the individual becomes blind to any positive aspects. Nwagwu (2008) advised that with effective management, all students can learn - no excuses or exceptions.

\subsection{Statement of the problem}

The organization and management of community services seem to be very poor in Nigerian universities. Students seem to pass through the university without rendering any voluntary service to the community. There is an atmosphere of high rate of insensitivity among university graduates, students and staff. Everyone seems to want one thing or another done for him or her without the individual thinking of what he or she can contribute to the community. Education is concerned with the total development of total personality of students and positive changes in their behavioral pattern. There is a need to find what is hindering the university administration from making community services operative as they are done in developed nations.

\subsection{Research questions}

The following research questions are raised to guide the research study:

1. Are voluntary community services necessary?

2. Do students render voluntary community services?

3. Do staff render voluntary community services?

4. Do students have positive attitude towards rendering voluntary community services?

5. Do staff have positive attitude towards rendering of voluntary community services?

6 . Are those who render voluntary community services recognized?

7. Does university's administration plan and organize community services?

8. What problems can be encountered in community services?

\subsection{Hypotheses}

The following null hypotheses are formulated from the research questions:

HO1 There will be no significant difference in the responses of academic and non-academic staff as to the importance of voluntary community service.

H02 There will be no significant difference in the willingness of academic and non-academic staff to participate in voluntary community services. 
HO3 There will be no significant difference in the willingness of male and female students to participate in voluntary community services.

\subsection{Significance of the Study}

This study on community services is very vital for Nigeria which is a developing country. The Nigerian government will benefit from knowing that the universities are religiously performing their functions as stated in the National Policy on Education. The university community will be happy to have sensitive individuals in the community who can help to move the community forward by making their various positive contributions. The University will be lively and people can interact with reasonable individuals and not greedy ones as one finds at present. Many students will benefits from people who are anxious to help in one way or another. Many will develop traits of good leadership. Many will learn to appreciate and respect others. Spirit of prejudices will diminish and replaced by the spirit of acceptance.

\section{Methodology}

The population of the study was all 27 federal Nigerian universities. A random sample of 6 federal Nigerian universities $(22.22 \%)$ was used for the study. From each university, a stratified random sampling method was used to select 100 male and 100 female students and 50 male and 50 female staff to participate in the study. A total of 600 male and 600 female students and 300 male and 300 female staff participated in the study.

The instrument used in gathering the data was the questionnaire designed by the researcher titled Management of Community Service Inventory (MCSI). The questionnaire was made up of two parts: Part A was based on respondents' personal data while Part B contained 15 questions bothering on planning and organization of community services, willingness of both staff and students to render voluntary community services, barriers to effective voluntary community servicing, management 's efforts to promote voluntary community services etc. The validity of the instrument was done by both experts in educational administration and educational psychology. Test-retest method was used to ascertain the reliability of the instrument. A Z-Test and common percent were the statistics used to analyze the data. The scores were rated in such a way that the score of $0-1.5$ is Low, 1.51-2.5 is Average, 2.51-3.5 is good and 3.51-4 is excellent.

\section{Results}

\section{Answers to Research Questions are in Table 1}

\section{Testing Hypotheses}

HO1: The first null hypothesis that states, that there will be no significant difference in the responses of academic and non-academic staff as to the importance of voluntary community services was tested with the data collected from the questionnaire. The analysis of data is presented in Table 2.

From Table 2, the calculated Z-Value at 0.05 -Confidence level is 1.18 while the Table Value was 1.96 . The first null hypothesis that states, that there will be no significant difference in the responses of academic and non-academic staff as to the importance of voluntary community services is therefore accepted. The academic staff response was good at 3.48 while that of the non-academics was excellent. However, the difference proved to be insignificant at a calculated Z-Value of 1.18 . Both academics and non-academics agreed that voluntary community service was necessary.

HO2: The second null hypothesis that states, that there will be no significant difference in the willingness of academic and non-academic staff to participate in voluntary community service is analyzed from the questionnaire and presented on Table 3.

From Table 3, the calculated Z-Value at 0.05 -Confidence Level is 14.64 while the Table value is 1.96 . The null hypothesis that states, that there will be no significant difference in the willingness of academic and non-academic staff to participate in voluntary community service is therefore rejected. The academics had a good response at an average of 3.36 for the question but their counter parts, the non-academics had an excellent response at an average of 3.67. The difference however is statistically significant. The non-academics have shown better response than the academics.

HO3: The third null hypothesis that states, that there will be no significant difference in the willingness of male and female students to participate in voluntary community services is analyzed from the questionnaire. The result is on Table 4.

From Table 4, the calculated Z-Value at 0.05 -Confidence level is 1.20 while the Table-Value is 1.96 . The null hypothesis that states, that there will be no significant difference in the willingness of male and female students to participate in voluntary community services is therefore accepted. Both male and female students' responses 
were rated excellent. The students in general have shown very high willingness to participate in the voluntary community services.

\section{Discussion}

From the data analysis, the general consensus was that voluntary community service is necessary. On the present nature of rendering voluntary service by both staff and students, $83 \%$ of the respondents agreed that students did not get involved in community service while $69 \%$ agreed that staff did not get involved in voluntary community service. Seventy-eight percent of students as opposed to $82 \%$ of staff had positive attitude towards rendering of community service. Those who rendered voluntary service were not motivated as was indicated by $94 \%$ of the respondents. Sixty percent of the respondents as opposed to $40 \%$ agreed that the university administration did not plan and organize voluntary community service.

For students' participation in voluntary community service, there was no significant difference in the responses of the students based on sex. Both male and female students showed very high willingness to participate in voluntary community service. For the staff participation in voluntary community service, there was a significant difference between the responses of academic and non-academic staff. With the average responses of 3.26 by the academic staff and 3.61 for the non-academic staff, the calculated Z-Value at 0.05-Confidence Level was 14.64 while the Table Value was 1.96. The non-academics showed very high willingness to participate in voluntary community service but the academics showed good acceptable willingness. The major obstacle indicated by the academics to their participation was workload. The researcher believes that if the academic staff would religiously manage their time, this obstacle will not be an issue.

\section{Conclusion}

From the foregoing data analysis, voluntary community service is not properly planned and managed in Nigerian universities. There is high willingness shown by both male and female students to participate but there is need for the university administration to put strategies in place in order to make the service operative. The staff also showed willingness to participate. Lecturers who complained of workload as a barrier to effective participation should be more conscious of their time management so that one or two hours allocated for the service would not be an issue.

\section{Recommendations}

In order to make voluntary community service to yield better results, the following are recommended:

- Conferences, workshops and seminars should be organized in order to create public awareness on the importance of community service.

- University Administration should plan and organize the voluntary community service.

- Rewards should be given to those who have performed exceptional services.

- For the students, credits of a maximum of (2) should be assigned to exceptional community service which is related to the student's major area.

- Student must show voluntary community services rendered before the student is graduated.

- Resources should be made available by various universities depending on the nature of service in question.

\section{References}

Aghenta, J. (2001). Educational planning: a turning point in education and development in Nigeria. Inaugural Lecture Series 58. University of Benin, 11.

Akerele, A. (2000). Black restoration is black responsibility: Nigeria and the black leadership imperative. Inaugural Lecture Series 54, University of Benin, 48.

Boss, J. (1994). Effects of the community service on the moral development of students. Journal of Moral Education, 2(23), 83-98.

Bungle, R., Philip, M. \& Hudson, M. (2004). The measure of service learning: research scales to assess students' experiences. American Psychology.

Kuh, G. (1995). Benefits of students' participation in community service. Ohio State University Press: Journal of Higher Education, 2(66).

Nwagwu, C. (2008). With effective management all students can learn: no excuses no exceptions. Inaugural Lecture Series 93, University of Benin. 
Serow, R. \& Dryden, J. (1990). Community service among college and university students, individual and institutional relationship. Journal of Adolescence, 99(25), 553-588.

Table 1. Answer to research questions

\begin{tabular}{|l|l|l|}
\hline Questions & YES & NO \\
\hline 1. Are voluntary community services necessary? & $100 \%$ & $0 \%$ \\
\hline 2. Do students render voluntary community services? & $17 \%$ & $83 \%$ \\
\hline 3. Do staff render voluntary community services? & $31 \%$ & $69 \%$ \\
\hline $\begin{array}{l}\text { 4. Do students have positive attitude towards rendering of } \\
\text { voluntary community services? }\end{array}$ & $78 \%$ & $22 \%$ \\
\hline $\begin{array}{l}\text { 5. Do staff have positive attitude towards rendering of } \\
\text { community services? }\end{array}$ & $82 \%$ & $18 \%$ \\
\hline $\begin{array}{l}\text { 6. Are those who render voluntary community services } \\
\text { recognized? }\end{array}$ & $6 \%$ & $94 \%$ \\
\hline $\begin{array}{l}\text { 7. Does university's administration plan and organize } \\
\text { community services? }\end{array}$ & $40 \%$ & $60 \%$ \\
\hline $\begin{array}{l}\text { 8. What problems can be encountered in community services? } \\
\text { buses by the recipients, insecurity, stress, } \\
\text { frustrations, inadequate resources, time } \\
\text { management, work-load, ill health, the } \\
\text { environmental factors etc. }\end{array}$ \\
\hline
\end{tabular}

Table 2. Test of significance difference in the responses of academic and non-academic staff as to the importance of voluntary community services

\begin{tabular}{|l|l|l|l|l|}
\hline Statistics & Academics & Non-Academics & Calculated Z-Value & Table Value \\
\hline Number & 300 & 300 & & \\
\hline Mean & 3.48 & 3.52 & 1.18 & 1.96 \\
\hline SD & .41 & .43 & & \\
\hline
\end{tabular}

Table 3. Test of significant difference in the willingness of academic and non-academic staff to participate in voluntary community services

\begin{tabular}{|l|l|l|l|l|}
\hline Statistics & Academics & Non-Academics & Calculated Z-Value & Table Value \\
\hline Number & 300 & 300 & & \\
\hline Mean & 3.26 & 3.67 & 14.64 & 1.96 \\
\hline SD & .37 & .32 & & \\
\hline
\end{tabular}

Table 4. Test of significant difference on the willingness of male and female students to participate in community services

\begin{tabular}{|l|l|l|l|l|}
\hline Statistics & Male & Female & Calculated Z-Value & Table Value \\
\hline Number & 600 & 600 & & \\
\hline Mean & 3.65 & 3.69 & 1.20 & 1.96 \\
\hline SD & 0.45 & 0.41 & & \\
\hline
\end{tabular}

